\title{
An assessment of genetic variability and relationships among wild-grown blackthorn (Prunus spinosa L.) plants based on RAPD markers
}

\author{
Y. Erturk ${ }^{1}$, S. Ercisli ${ }^{2}$, D. Maghradze ${ }^{3}$, E. Orhan $^{2}$ and G. Agar $^{4}$ \\ ${ }^{1}$ Hamza Polat Vocational School, Ataturk University, Ispir-Erzurum, Turkey \\ ${ }^{2}$ Department of Horticulture, Faculty of Agriculture, \\ Ataturk University, Erzurum, Turkey \\ ${ }^{3}$ Department of Genetics and Breeding, \\ Institute of Horticulture and Vine Making, Tbilisi, Georgia \\ ${ }^{4}$ Department of Biology, Faculty of Arts and Science, \\ Ataturk University, Erzurum, Turkey \\ Corresponding author: S. Ercisli \\ E-mail: sercisli@hotmail.com
}

Genet. Mol. Res. 8 (4): 1238-1244 (2009)

Received June 2, 2009

Accepted July 25, 2009

Published October 13, 2009

\begin{abstract}
Prunus spinosa, blackthorn, exists as wild populations that inhabit uncultivated uplands of Coruh Valley in the northeastern part of Turkey; the fruit is used to make preserves. We examined genetic diversity in wild-grown Prunus spinosa; 16 individual plants from wild populations of Coruh Valley were sampled and subjected to RAPD (random amplified polymorphic DNA) analysis. We tested 51 random decamer primers; 15 of them gave reproducible polymorphic patterns. These 15 primers produced 226 bands, of which $65 \%$ were polymorphic. A UPGMA dendrogram clearly divided the genotypes into four groups; we concluded that RAPD analysis can be used for examining genetic relatedness among blackthorn genotypes.
\end{abstract}

Key words: Blackthorn; Genetic diversity; Prunus spinosa; Random amplified polymorphic DNA 


\section{INTRODUCTION}

Plums are one of the widely grown stone fruits and they are characterized by a firm flesh when unripe, becoming softer to melting at maturity. They can be eaten fresh but are most often processed, mostly to prunes or distilled drinks (Catherine and Ginies, 2009).

Plums belong to the subgenus Prunophora and include more than 20 species with abundant variations in their morphology. In addition, the chromosome number of plum species within the subgenus Prunophora varies from diploid to tetraploid. Cherry plums (Prunus cerasifera Ehrh) and Japanese plums are diploid, blackthorn (Prunus spinosa L.) is tetraploid and European plums (Prunus domestica L.) are hexaploid (Okie and Weinberger, 1996). According to this derivate system, there is a wide diversity among plums both at the inter- and intraspecies level. This diversity is particularly evident in the characteristics of the fruit (size, shape, color, texture, aroma), and plant (shrubs to large trees, spreading to upright, thick to thin leaves, and early to late blooming) (Ramming and Cociu, 1990).

Prunus spinosa is thought to be indigenous to Southern Europe, Turkey and Armenia (Ramming and Cociu, 1990). The fruits are sometimes only $20 \mathrm{~mm}$ in size, sour and highly astringent. The roots and bark are used for tanning. Dried leaves are used to make a tea, and dried flowers and fruits are important in folk medicine (Buttner, 2001). Turkey is one of the genetic centers for the species $P$. cerasifera Ehrh., $P$. insititia L., $P$. spinosa L., and $P$. domestica L. (Ercisli, 2004). Trees prefer calcareous soils in rocky places and on ledges, at either high or low elevations. It is more abundant in North, West and South Anatolia in scrub and forest remnants between 0-1700 m a.s.1. (Browicz, 1972).

Genetic variation, or diversity, in plums in Turkey has been traditionally assessed using morphological traits, which are highly influenced by environmental factors or developmental stage of plants (Ozakman et al., 1993; Ayanoglu, 1995; Onal and Cinsoy, 2003; Ertekin et al., 2006). However, little is known about the structure and the genetic diversity in the local germplasm. Due to the predominantly out-crossing nature of most plum species, existing natural seed-propagated plum populations are highly heterozygous (Ercisli, 2004; Halasz et al., 2007) and show environmentally dependent morphoanatomical traits. To overcome this problem, environment-free techniques must be used to determine genetic diversity. Molecular marker techniques may offer great promise to determine genetic diversity in plant species. Polymerase chain reaction (PCR)-based markers have been extensively applied in genetic diversity studies in plums (Gregor et al., 1994; Shimada et al., 1999; Goulao et al., 2001; Lisek et al., 2007; Ayanoglu et al., 2007; Hend et al., 2009; Ilgin et al., 2009). All these studies revealed reliable genetic differences among materials.

Random amplified polymorphic DNA (RAPD) markers have proven to be a reliable marker system for genetic fingerprinting and also for determining the genetic relationships among germplasm collections. RAPD markers have the advantages of simplicity and the ability to detect relatively small amounts of genetic variation and also need no prior information on the genome (Ercisli et al., 2007; Koc et al., 2009).

In the present study, we report the successful use of the RAPD method to examine the molecular polymorphisms as well as genetic relationships among wild-grown blackthorn (Prunus spinosa L.) genotypes. 


\section{MATERIAL AND METHODS}

Leaf samples from 16 wild-grown blackthorn (Prunus spinosa L.) were collected in Coruh Valley. The leaves were stored immediately at $-80^{\circ} \mathrm{C}$ for DNA extraction. Genomic DNA was extracted from powdered (ground in liquid nitrogen) plant materials using a modified method described by Lin et al. (2001). Approximately 10-15-mg tissue samples from each plant sample were snap-frozen in liquid nitrogen in 2-mL Eppendorf tubes. A volume of 1000 $\mu \mathrm{L}$ DNA extraction buffer [100 mM Tris-HCl, pH 8.0; 50 mM EDTA, $\mathrm{pH} 8.0 ; 500 \mathrm{mM} \mathrm{NaCl}$; $2 \% \operatorname{SDS}(\mathrm{w} / \mathrm{v}) ; 2 \%$ 2-mercaptoethanol (v/v); $1 \% \mathrm{PVP}(\mathrm{w} / \mathrm{v})]$ was added and the contents mixed well. The mixture was incubated at $65^{\circ} \mathrm{C}$ in a water bath for $40 \mathrm{~min}$ with intermittent shaking at 5 -min intervals. The mixture was centrifuged at $12,000 \mathrm{~g}$ for $15 \mathrm{~min}$ at $4^{\circ} \mathrm{C}$. The supernatant was transferred to a clean $1.5-\mathrm{mL}$ tube, mixed with an equal volume of phenol:chloroform:isoamyl alcohol (25:24:1), and centrifuged. The supernatant was collected and mixed with 1/10 volume $10 \% \mathrm{CTAB}-0.7 \mathrm{M} \mathrm{NaCl}$ in a clean tube. After centrifugation, the supernatant was collected, and an equal volume of chloroform:isoamyl alcohol (24:1) was added, followed by gentle mixing. The DNA was precipitated by the addition of 0.6 volume of freezer-cold isopropanol, for $10 \mathrm{~min}$ at $-20^{\circ} \mathrm{C}$. The DNA was pelleted by centrifugation $(12,000 \mathrm{~g}, 10 \mathrm{~min})$, and the isopropanol was poured off; the DNA was allowed to air-dry before being dissolved in $100 \mu \mathrm{f} \mathrm{TE} \mathrm{buffer.}$

The samples were screened for RAPD variation using the standard 10-base primers supplied by Operon Technologies, Inc., USA. A 30- $\mu \mathrm{L}$ reaction cocktail was prepared as follows: $3.0 \mu \mathrm{L}$ 10X buffer, $1.2 \mu \mathrm{L}$ dNTPs $(10 \mathrm{mM}), 1.2 \mu \mathrm{L}$ magnesium chloride $(25 \mathrm{mM}), 2.0$ $\mu \mathrm{L}$ primer $(5 \mu \mathrm{M}), 0.4 \mu \mathrm{L} \mathrm{Taq}$ polymerase $(5 \mathrm{U}), 19.2 \mu \mathrm{L}$ water, and $3.0 \mu \mathrm{L}$ sample DNA (100 $\mathrm{ng} / \mu \mathrm{L})$. A total of 51 RAPD primers were tested in this study, and the polymorphisms obtained with the primers are shown in Table 1.

The thermocycler (Eppendorf Company) was programmed as follows: $2 \mathrm{~min}$ at $95^{\circ} \mathrm{C} ; 2$ cycles of $30 \mathrm{~s}$ at $95^{\circ} \mathrm{C}, 1 \mathrm{~min}$ at $37^{\circ} \mathrm{C}, 2 \mathrm{~min}$ at $72^{\circ} \mathrm{C} ; 2$ cycles of $30 \mathrm{~s}$ at $95^{\circ} \mathrm{C}, 1 \mathrm{~min}$ at $35^{\circ} \mathrm{C}, 2 \mathrm{~min}$ at $72^{\circ} \mathrm{C} ; 41$ cycles of $30 \mathrm{~s}$ at $94^{\circ} \mathrm{C}, 1 \mathrm{~min}$ at $35^{\circ} \mathrm{C}, 2 \mathrm{~min}$ at $72^{\circ} \mathrm{C}$; followed by a final 5 -min extension at $72^{\circ} \mathrm{C}$, then cooling to $4^{\circ} \mathrm{C}$. The markers were checked twice for their reproducibility.

The PCR products $(27 \mu \mathrm{L})$ were mixed with $6 \mathrm{X}$ gel loading buffer $(3 \mu \mathrm{L})$ and loaded onto an agarose $(1.5 \% \mathrm{w} / \mathrm{v})$ gel in $0.5 \mathrm{X}$ TBE (Tris-borate-EDTA) buffer, and electrophoresis was at $70 \mathrm{~V}$ for $150 \mathrm{~min}$. The gel was stained in an ethidium bromide solution $(2 \mu \mathrm{L} / 100 \mathrm{~mL}$ $1 \mathrm{X}$ TBE buffer) for $40 \mathrm{~min}$, and the bands were visualized under UV in a Bio Doc Image Analysis System with the Uvisoft analysis package (Cambridge, UK).

The positions of scorable RAPD bands were transformed into a binary character matrix (' 1 ' for the presence and ' 0 ' for the absence of a band at a particular position), which was entered in the RAPDistance computer program (Armstrong et al., 1994). These data were used for the calculation of pairwise genetic distances between cultivars using the Jaccard coefficient (JC). The computer program calculated the degree of genetic dissimilarity between each pair of the 12 cultivars using the simple equation: $\mathrm{JC}=1-a /(a+b+c)$, where " $a$ " is the number of bands shared by plant " $x$ " and plant " $y$ ", " $b$ " is the number of bands in plant " $x$ ", and " $c$ " is the number of bands in plant " $y$ ". The JC ignores the absence of matches. The distance matrix was used for cluster analysis using the unweighted pair-group method with arithmetic averages (UPGMA). The MXCOMP module was used to compute the cophenetic correlation, i.e., to test the goodness-of-fit of the cluster analysis to the similarity matrix. 


\section{RESULTS} Figure 1 .

The results of RAPD analysis of 16 blackthorn genotypes are given in Table 1 and

As mentioned before, we used a total of 51 decamer oligonucleotide primers supplied by Operon Technologies, Inc., to investigate genetic relationships among genotypes. Among the 51 primers, 36 primers did not produce any polymorphic bands or did not amplify clear products. Therefore, the remaining 15 primers, which produced good and reproducible polymorphic bands among the 16 blackthorn genotypes, were used for further analysis.

These 15 primers produced a total of 226 DNA fragments, and among them 147 fragments were polymorphic and 79 fragments were monomorphic (Table 1). The highest number of polymorphisms was observed with primer OPA08 (83\%), while the lowest was obtained with primer OPA13 (50\%). The size of the amplified fragments ranged from 400 to $2500 \mathrm{bp}$. Each primer generated 10 to 18 RAPD bands, and $65 \%$ of the bands were polymorphic (Table 1).

\begin{tabular}{lcccc}
\multicolumn{2}{c}{ Table 1. List of the selected primers and the degree of polymorphism obtained among 16 blackthorn genotypes. } \\
\hline Primer code & Sequence 5' $\rightarrow 3^{\prime}$ & $\begin{array}{c}\text { Polymorphic } \\
\text { bands }\end{array}$ & $\begin{array}{c}\text { Monomorphic } \\
\text { bands }\end{array}$ & $\begin{array}{c}\text { Percentage of } \\
\text { polymorphic markers }\end{array}$ \\
\hline OPA02 & TGCCGAGCTG & 11 & 6 & 65 \\
OPA03 & 10 & 6 & 63 \\
OPA04 & AGTCAGCCAC & 9 & 5 & 64 \\
OPA08 & AATCGGGCTG & 14 & 3 & 83 \\
OPA13 & GTGACGTAGG & 5 & 6 & 50 \\
OPA17 & CAGCACCCAC & 10 & 7 & 59 \\
OPB07 & GACCGCTTGT & 12 & 6 & 67 \\
OPB12 & GGTGACGCAG & 10 & 6 & 63 \\
OPG10 & CCTTGACGCA & 11 & 4 & 73 \\
OPH11 & AGGGCCGTCT & 10 & 4 & 72 \\
OPH14 & CTTCCGCAGT & 10 & 4 & 67 \\
OPH17 & ACCAGGTTGG & 11 & 6 & 73 \\
OPM01 & CACTCTCCTC & 7 & 6 & 54 \\
OPY15 & GTTGGTGGCT & 8 & 5 & 57 \\
OPW17 & AGTCGCCCTT & 9 & 79 & 64 \\
Polymorphism (average) & GTCCTGGGTT & & & 65 \\
Total & & 147 &
\end{tabular}

The dendrogram obtained from the RAPD markers grouped the 16 blackthorn genotypes into four main clusters. The first cluster included genotypes cp1, cp6, cp7, and cp11, the second cluster included genotypes cp2, сp3, сp4, сp5, сp10, сp12, сp14, and cp16, the third cluster included genotypes cp8, cp9, and cp15, and the last cluster included genotype cp13 (Figure 1). The highest similarity was observed between genotypes cp6, and cp11 (0.72) and the lowest similarity was between genotypes cp1, and cp13 (0.55). The cophenetic correlation coefficient indicated a correlation of $r=0.87$ between the similarity matrix and the UPGMA dendrogram, indicating a good representation of the relationship among the genotypes. 


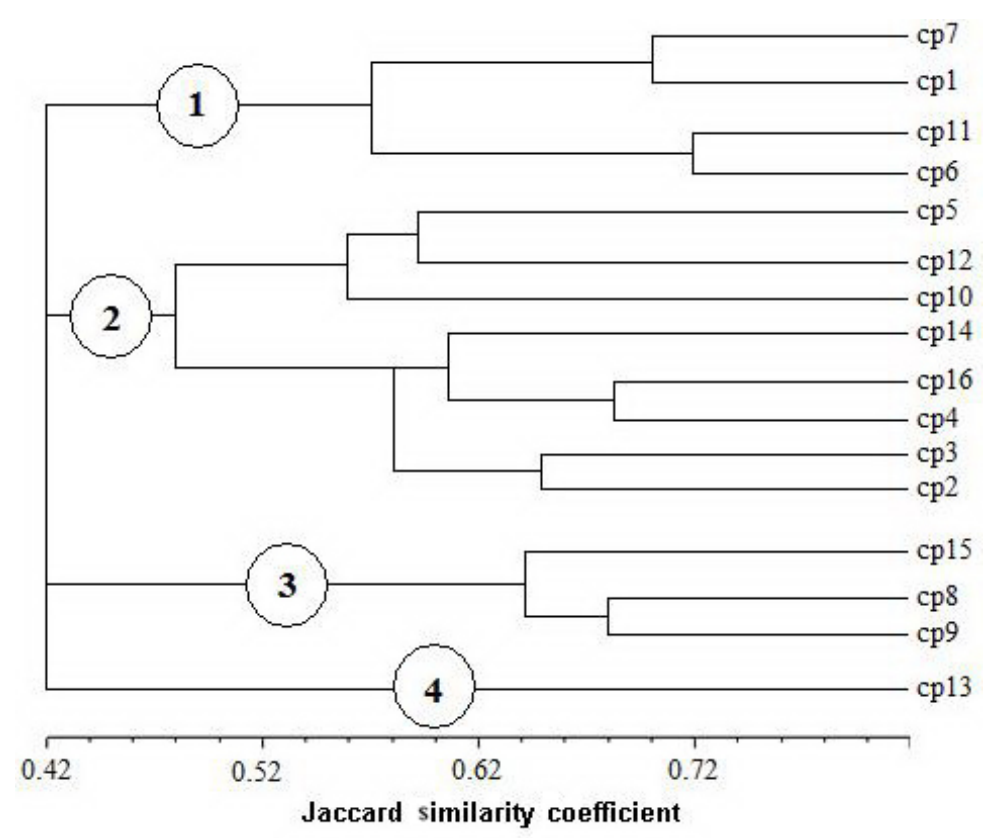

Figure 1. UPGMA dendrogram of sixteen blackthorn genotypes based on 15 RAPD primers.

\section{DISCUSSION}

This study showed that there was an important genetic diversity at the DNA level among the blackthorn genotypes sampled from Coruh Valley in Turkey. In fact, we obtained a high number polymorphic bands (147), which is considerably important compared to other results reported by Shimada et al. (1999) and Lisek et al. (2007) using 20 and 13 RAPD primers, respectively. Polymorphisms at the DNA level have been used in many investigations to determine the genetic diversity in plums. Previous molecular studies on plums using RAPD markers revealed a wide genetic polymorphism among different plum accessions ranging from 20 to 98\% (Gregor et al., 1994; Ortiz et al., 1997; Bellini et al., 1998; Shimada et al., 1999; Lisek et al., 2007; Liu et al., 2007; Hend et al., 2009). This wide variation is normal because plums are very complex groups including diploid, tetraploid and hexaploid species and because flower biology also differs in different plum groups (Ercisli, 2004). Prunus spinosa is allotetraploid ( $2 \mathrm{n}=4 x=32$; Reynders-Aloisi and Grellet, 1994). Allopolyploids are characterized by fixed (i.e., nonsegregating) heterozygosity, resulting from the combination of divergent parental genomes; bivalent formation occurs at meiosis, and disomic inheritance operates at each locus. Insect-pollinated plum cultivars belong to Prunus salicina, and Prunus domestica frequently reproduces vegetatively, but Prunus spinosa as a wild species is pollinated by birds and animals. The seeds of the species are mainly dispersed by birds and animals, resulting in high heterozygosis. As is well known that polyploidy plants have a higher genetic diversity than do diploid ones because polyploidy taxa are often formed through hybridization, which 
results in high heterozygosity (Soltis and Soltis, 2000). Ayanoglu et al. (2007) characterized a total of 20 cherry plum accessions belonging to Prunus cerasifera by amplified fragment length polymorphism markers, and obtained 6-18\% polymorphism, indicating lower genetic diversity among diploid Prunus cerasifera accessions. On the other hand, $P$. spinosa is a wild shrub, which has not undergone any selection pressure imposed by humans for its domestication. In the absence of such selection pressure, it is most probable that nuclear DNA variability is maintained in nature. Also, high DNA variation may be related to a high generation turnover for this shrub species and hence a greater probability for mutations to be fixed in later generations. Along with high nuclear DNA diversity, this species also has high chloroplast DNA diversity within and among populations (Mohanty et al., 2000).

Accordingly, RAPD analysis revealed patterns of genotypic variation among blackthorn genotypes, indicating that these genotypes do not reproduce in a vegetative manner. The results of the present study may also benefit breeders in selecting the most diverse genotypes with similar fruit characteristics to begin crossing and selection programs.

\section{REFERENCES}

Armstrong J, Gibbs A, Peakall R and Weiller G (1994). The RAPDistance Package. Available at [http:/life.anu.edu.au/ molecular/software/rapd.htm]. Accessed June 14, 2004.

Ayanoglu H (1995). Table Plum Selection from East Mediterranean Region in Turkey. PhD thesis, Cukurova University, Adana. Ayanoglu H, Bayazit S, Inan G, Bakir M, et al. (2007). AFLP analysis of genetic diversity in Turkish green plum accessions (Prunus cerasifera L.) adapted to the Mediterranean region. Sci. Hortic. 114: 263-267.

Bellini E, Giordani E, Nencetti V and Pafetti D (1998). Genetic relatioships in Japanese plum cultivars by molecular markers. Acta Hort. 478: 918-924.

Browicz K (1972). Prunus. In: Flora of Turkey and East Aegean Island. Vol. 4 (Davis PH, ed.). Edinburgh University Press, Edinburgh, 8-12.

Buttner R (2001). Prunus. In: Mansfeld's Encyclopedia of Agricultural and Horticultural Crops (Hanelt P and Institute of Plant Genetics and Crop Plant Research, eds.). Springer-Verlag, Berlin [ISBN-10: 3540410171; ISBN-13: 9783540410171], 517-523.

Catherine MGC and Ginies RC (2009). Comparison of the cell wall composition for flesh and skin from five different plums. Food Chem. 114: 1042-1049.

Ercisli S (2004). A short review of the fruit germplasm resources of Turkey. Genet. Res. Crop Evol. 51: 419-435.

Ercisli S, Agar G, Orhan E, Yildirim N, et al. (2007). Interspecific variability of RAPD and fatty acid composition of some pomegranate cultivars (Punica granatum L.) growing in Southern Anatolia Region in Turkey. Biochem. Syst. Ecol. 35: 764-769.

Ertekin C, Gozlekci S, Kabas O, Sonmez S, et al. (2006). Some physical, pomological and nutritional properties of two plum (Prunus domestica L.) cultivars. J. Food Eng. 75: 508-514.

Goulao L, Monte-Corvo L and Oliveira CM (2001). Phenetic characterization of plum cultivars by high multiplex ratio markers: amplified fragment length polymorphisms and inter-simple sequence repeats. J. Am. Soc. Hort. Sci. 126: 72-77.

Gregor D, Hartmann W and Stösser R (1994). Cultivar identification in Prunus domestica using random amplified polymorphic DNA markers. Acta Hort. 359: 33-40.

Halasz J, Hegedus A, Szabo Z, Nyeki J, et al. (2007). DNA-based S-genotyping of Japanese plum and pluot cultivars to clarify incompatibility relationships. HortScience 42: 46-50.

Hend BT, Ghada B, Sana BM, Mohamed M, et al. (2009). Genetic relatedness among Tunisian plum cultivars by random amplified polymorphic DNA analysis and evaluation of phenotypic characters. Sci. Hortic. 121: 440-446.

Ilgin M, Kafkas S and Ercisli S (2009). Molecular characterization of plum cultivars by AFLP markers. Biotechnol. Biotechnol. Eq. 23: 1189-1193.

Koc A, Akbulut M, Orhan E, Celik Z, et al. (2009). Identification of Turkish and standard apple rootstocks by morphological and molecular markers. Genet. Mol. Res. 8: 420-425.

Lin RC, Ding ZS, Li LB and Kuang TY (2001). A rapid and efficient DNA minipreparation suitable for screening transgenic plants. Plant Mol. Biol. Rep. 19: 379.

Lisek A, Korbin M, Rozpara E and Zurawicz E (2007). Plum cultivar DNA polymorphism generated with RAPD and

Genetics and Molecular Research 8 (4): 1238-1244 (2009)

CFUNPEC-RP www.funpecrp.com.br 
ISSR markers. Acta Hort. 734: 281-285.

Liu W, Li S, Zhang A and Liu D (2007). Genetic diversity revealed by RAPD markers in plum collection of China. Acta Hort. 734: 287-294.

Mohanty A, Martín JP and Aguinagalde I (2000). Chloroplast DNA diversity within and among populations of the allotetraploid Prunus spinosa L. Theor. Appl. Genet. 100: 1304-1310.

Okie WR and Weinberger JH (1996). Plums. In: Fruit Breeding. Vol. I. Tree and Tropical Fruits (Janick J and Moore JN, eds.). Wiley, New York, 559-607.

Onal MK and Cinsoy AF (2003). The determination of relationship among pomological characteristics and classified of some plum (Prunus salicina Lindl., Prunus domestica L.) cultivars by using principle component analysis. Akdeniz Univ. Agric. Fac. J. 16: 43-50.

Ortiz A, Renaud R, Calzada I and Ritter R (1997). Analysis of plum cultivars with RAPD markers. J. Hortic. Sci. 72: 1-9.

Ozakman S, Onaz K, Karabiyik N and Ozkarakas I (1993). Plum Cultivar Adaptation. Aegean Agricultural Research Institute of the Ministry of Agriculture and Rural Affairs, Izmir.

Ramming DW and Cociu V (1990). Plums (Prunus). Acta Hort. 290: 1-63.

Reynders-Aloisi S and Grellet F (1994). Characterization of the ribosomal DNA units in two related Prunus species ( $P$. cerasifera and P. spinosa). Plant Cell Rep. 13: 641-646.

Shimada T, Hayama H, Haji T, Yamaguchi M, et al. (1999). Genetic diversity of plums characterized by random amplified polymorphic DNA (RAPD) analysis. Euphytica 109: 143-147.

Soltis Ps and Soltis DE (2000). The role of genetic and genomic attributes in the success of polyploids. Proc. Natl. Acad. Sci. U. S. A. 97: 7051-7057. 